\title{
Evaluation of Coconut Hybrids Developed for High Nut and Copra
}

\author{
Vijay Selvaraj $\mathrm{KS}^{1 *}$, Rajendran $\mathrm{R}^{1}$, Saraladevi $\mathrm{D}^{2}$ and Maheswarappa $\mathrm{HP}^{3}$ \\ ${ }^{1}$ Coconut Research Station, India \\ ${ }^{2}$ Horticulture College \& Research Institute (W), India \\ ${ }^{3}$ ICAR - Central Plantation Crops Research Institute, India
}

Submission: March 03, 2017; Published: April 05, 2017

"Corresponding author: Vijay Selvaraj KS, Coconut Research Station, TNAU, Veppankulam-614-906, Tamil Nadu, India, Email: ksvijayselvaraj@gmail.com

\begin{abstract}
An evaluation trial conducted over 30 years on coconut hybrid combinations has resulted in identification of a superior, high yielding Tall $\mathrm{x}$ Tall hybrid, released as VPM 5 involving Laccadive Ordinary as female parent and Cochin China as male parent. This hybrid is better performing over other hybrids and local check with higher fruit yield (161 nuts palm-1year-1), higher copra out turn (24.1 kg palm-1 year- $1,4.2 \mathrm{t} \mathrm{ha}-1$ year- 1 ) with an estimated oil recovery of 2.90 tonnes ha- 1 under irrigated conditions of Tamil Nadu. The palms of the hybrid took on an average of 45 months for initiation of flowering, possess good tender nut water quality (TSS $5.5^{\circ}$ Brix) and higher quantity ( $300 \mathrm{ml}$ per tender nut). The hybrid recorded 44 percent more nut yield, 48 percent more copra yield and 48.2 percent more oil yield over the released Tall x Dwarf hybrid 'VHC 1'. The seedlings of the hybrid are more vigorous, producing higher number of leaves within 12 months, having higher leaf area and dry weight indicating precocity in growth and development. The flowering, morphological and fruit component traits of the hybrid were compared with parental palms are found superior. The characteristics of this hybrid and its performance indicated the potential to increase the productivity and over all coconut production.
\end{abstract}

Keywords: Coconut hybrids; Development and evaluation; Nut; Copra yield

\section{Introduction}

India occupies a predominant position in respect of production of coconut in the world. Coconut is grown in 1.94 million ha in 19 states and 3 Union Territories of the country producing 15730 million nuts with an average productivity of 8303 nuts per ha or 44.27 nuts/palm/year. Traditional areas of coconut in India are the states of Kerala, Tamil Nadu, Karnataka, Andhra Pradesh, Orissa, Goa, West Bengal, Pondicherry, Maharashtra and Islands of Lakshadweep and Andaman and Nicobar. Non-traditional areas are the states of Assam, Gujarat, Madhya Pradesh, Bihar, Tripura, Manipur, Nagaland and Arunachal Pradesh. The four southern states put together account for more than $90 \%$ of the total production in the country (Kerala 36.88\%, Tamil Nadu 34.11\%, Karnataka 13.83\%, Andhra Pradesh 6.16\% and other states 9.0\%).(www. nabard.org/english/plant_coconut).

The discovery of hybrid vigour in coconut by Patel [1] in a cross between West Coast Tall and Chow ghat Green Dwarf made in 1932 at Coconut Research Station, Nileshwar was a significant landmark in the history of crop improvement in coconut. This important finding paved way for the successful breeding programmes in coconut not only in India but also in other countries like Philippines, Indonesia, Sri Lanka, Cote d'Ivoire and Jamaica. Coconut research station Veppankulam was established in 1958 with mandate of evolving promoting new high yielding coconut varieties/hybrids and identification of coconut genotypes suitable for coastal region of Tamil Nadu. Over the period of research conducted, four hybrids and two varieties were released from this station so far. Those are, first coconut hybrid VHC 1 (ECT X Green dwarf) was released in 1982, VHC 2 (East Coast Tall X Malayaisan Yellow Dwarf), in 1988, VHC 3 (East Coast Tall X Malaysian orange dwarf) and tall varieties VPM 3 was selection from Andaman Ordinary Tall in 1994 and VPM 4 was selection from West Coast Tall in 2012. The latest hybrid is VPM 5 is first hybrid developed with tall parents (LCT as female parent and CCNT as male parent). The development of VPM 5 hybrid was initiated with objective of high number of nuts/palm/ annum and details about the VPM 5 hybrid coconut are briefed in this article. 


\section{Materials and Methods}

The experiment was conducted at Tamil Nadu Agricultural University - Coconut Research Station, Veppankulam (TNAU-CRS, VPM), Tamil Nadu situated at latitude of $10^{\circ} 29^{\prime} \mathrm{N}$ and longitude $79^{\circ} 23^{\prime} \mathrm{E}$ at an altitude of $20 \mathrm{~m}$ from the mean sea level. The average maximum temperature is $42{ }^{\circ} \mathrm{C}$ in summer and $33^{\circ} \mathrm{C}$ in winter while the average minimum temperature is $28^{\circ} \mathrm{C}$ in summer and $23^{\circ} \mathrm{C}$ in winter. The annual rainfall varied between 800 to $1200 \mathrm{~mm}$

The hybridization crossing was done with tall parents (LCT as female parent and CCNT as male parent) during 1984-85. The crossed nuts were raised in nursery separately and selection was made with superior seedlings during 1986. The 60 number of hybrid seedling were planted in B block of CRS farm maintained over a years. The stabilized yield was recorded observed in 15 years old palm on 2001. So data was recorded for nut yield, oil content and physiological traits over 10 years from 2001 to 2014 with 42 hybrid palms.

Table 1: Cumulative mean performance of LCT x CCNT (VPM 5).

\begin{tabular}{|c|c|c|c|c|}
\hline S.No & Character & LCT X CCNT & Hybrid Check & Local Tall Check \\
\hline & & (VPM 5) & VHC-1 & ECT \\
\hline 1 & $\begin{array}{l}\text { Mean annual fruit yield (no } \\
\text { s./palm) }\end{array}$ & 161 & 112 & 99 \\
\hline $\begin{array}{l}\% \text { increase over the check } \\
\text { of nut yield }\end{array}$ & 43.8 & 62.6 & & \\
\hline 2 & Fruit yield/ha/year (in'000) & 28.18 & 19.6 & 17.33 \\
\hline 3 & Copra content (g/nut) & 149.8 & 142.8 & 133.1 \\
\hline 4 & $\begin{array}{l}\text { Copra out turn/palm/year } \\
(\mathrm{kg})\end{array}$ & 24.12 & 16.33 & 13.18 \\
\hline $\begin{array}{l}\% \text { increase over the check } \\
\text { for copra out turn }\end{array}$ & 47.7 & 83 & & \\
\hline 5 & Copra out turn (t/ha/year) & 4.22 & 2.86 & 2.31 \\
\hline 6 & Copra oil content (\%) & 70 & 69.5 & 68.4 \\
\hline \multirow[t]{2}{*}{7} & $\begin{array}{l}\text { Estimated oil yield (t/ha/ } \\
\text { year) }\end{array}$ & 2.95 & 1.99 & 1.58 \\
\hline & $\begin{array}{l}\% \text { increase over the check } \\
\text { for oil yield }\end{array}$ & & 48.2 & 86.7 \\
\hline
\end{tabular}

Nut Parameters: Nut parameters were recorded for 3 hybrids LCT x CCNT, CCNT x LCT, LCT x PHOT and the checks, VHC 1, VHC 2 and VHC 3 The mean value are given below.

Table 2: Nut Parameters of LCT x CCNT (VPM 5) compared with released hybrids.

\begin{tabular}{|c|c|c|c|c|c|}
\hline Hybrid & Whole Nut Wt. (G) & Dehusked Nut Wt. (G) & $\begin{array}{c}\text { Kernel Thickness } \\
(\mathbf{C m})\end{array}$ & Kernel Wt (G) & Shall Wt. (G) \\
\hline LCTx CCNT (VPM5) & 1052 & 567 & 1.17 & 275 & 145 \\
\hline & & & & & \\
\hline CCNT x LCT & 1150 & 687 & 1.05 & 312 & 170 \\
\hline LCT x PHOT & 1138 & 675 & 1.2 & 297 & 165 \\
\hline VHC 1 & 1007 & 548 & 1.1 & 327 & 135 \\
\hline VHC 2 & 978 & 610 & 1.15 & 283 & 175 \\
\hline VHC 3 & 1208 & 662 & & & 175 \\
\hline
\end{tabular}


Table 3: Mean performance of nut characters of LCT x CCNT.

\begin{tabular}{|c|c|c|c|c|}
\hline Sl.No. & Characters & VPM 5 & Hybrid Check & Local Check \\
\hline & & LCTxCCNT & VHC 1 & ECT \\
\hline 1 & Whole fruit weight (g) & $958.0 \pm 21.2$ & $818.4 \pm 30.1$ & $380.7 \pm 36.2$ \\
\hline 2 & Husked fruit weight (g) & $454.4 \pm 15.7$ & $424.3 \pm 18.9$ & $1.2 \pm 0.3$ \\
\hline 3 & Kernel thickness (cm) & $1.4 \pm 0.2$ & $1.2 \pm 0.3$ & $243.6 \pm 5.1$ \\
\hline 5 & Kernel weight (g/nut) & $243.7 \pm 6.7$ & $236.1 \pm 7.2$ & $133.1 \pm 9.3$ \\
\hline 6 & Copra content (g/nut) & $149.8 \pm 8.3$ & $142.8 \pm 7.6$ & $68.4 \pm 1.8$ \\
\hline 7 & Oil content (\%) & $70.0 \pm 2.5$ & $69.5 \pm 1.6$ & 99.6 \\
\hline & Oil yield (g/nut) & $104.9 \pm 3.1$ & $99.3 \pm 4.0$ & $9.0 \pm 5.2$ \\
\hline
\end{tabular}

Table 4: Quality analysis of tender nut characters of LCT x CCNT (VPM 5).

\begin{tabular}{|c|c|c|c|c|}
\hline Sl.No. & Characters & LCTxCCNT (VPM 5) & Checks & ECT \\
\hline & & & VHC 1 & $205.5 \pm 34.3$ \\
\hline 2 & Quantity of water (ml) & $285.5 \pm 25.5$ & $220.7 \pm 30.1$ & 2 \\
\hline 3 & Sweetness of water* & 3 & 2 & 2 \\
\hline 4 & $\begin{array}{c}\text { Sweetness of tender nut } \\
\text { kernel* }^{*}\end{array}$ & 3 & $4.4 \pm 0.51$ & $4.1 \pm 0.48$ \\
\hline 5 & TSS ( ${ }^{\circ}$ Brix) & $4.8 \pm 0.42$ & $4.4 \pm 0.43$ & $4.1 \pm 0.39$ \\
\hline
\end{tabular}

*Standard protocols published by Bioversity/CPCRI

1: Poor; 2: Average; 3: Good; 4:Very good

In Experiment III, highest annual nut yield was found in LCOT $\mathrm{x}$ CCNT (161.5, 84.2, 180, 125.3 and 198.2 nuts/palm/year during the year 2010-11, 2011-12, 2012-13, 2013-14, 2014-15 and 201516 respectively. The information generated from earlier studies the fatty acid profile, reaction to environmental stresses, biochemical constituents of seedlings of hybrid combination [1-6]. Were collected and used. Among the hybrids, Hybrid LCT x CCNT showed promising yield among the years. Average stabilized yield for the hybrid is 161nuts/palm/ year. The physiological parameters of LCT X CCNT were also recorded. The results revealed that enzyme nitrate reductase was $9.3 \mu \mathrm{mol} / \mathrm{NO} / \mathrm{g} / \mathrm{kg}$, Total chlorophyll of $3.12 \mathrm{mg} / \mathrm{g}$ and protein of $12.84 \mathrm{mg} / \mathrm{g}$. The standard heterosis over ECT was $64.5[7,8]$.

LCT $x$ CCNT is a tall $\mathrm{x}$ tall hybrid with circular crown shape, biometric observations was recorded for the hybrid it revealed that Total number of leaves (34.7), Length of petiole (1.22m), Length of leaflet bearing portion (3.61m), Number of leaflets (right) (103.9), Number of leaflets (left) (104.3), Length of leaflet (1.28m), Breadth of leaflet $(5.6 \mathrm{~cm})$ and Number of leaf scars in $1 \mathrm{~m}$ length (35.2). Nut characteristics of LCT $\mathrm{x}$ CCNT revealed that Whole nut wt. of (1052g), dehusked nut wt (567g), kernel thickness (1.17cm), kernel wt. (275g), shell wt. (145g) and copra wt. (149.8g). LCT x CCNT consistently recorded the highest nut yield over the years.

\section{References}

1. Patel JS (1937) Coconut Breeding. Proceedings of Association of Economic Biologists 5: 25.

2. CPCRI (1991) Annual Report 1990-1991. Central Plantation Crops research Institite, ICAR, Kasaragod, India, p. 154.

3. CPCRI (1992) Annual Report 1991-1992. Central Plantation Crops research Institite, ICAR, Kasaragod, India, p. 188.

4. CPCRI (1994) Annual Report 1993-1994. Central Plantation Crops research Institite, ICAR, Kasaragod, India, p. 193.

5. Shivsankar S, Chempakam B (1999) Germination and early seed growth. In: Rajagopal V, Ramadasan A (Eds.), Advances in Plant Physiology and Biochemistry of Coconut Palm. Asian and Pacific Coconut Community, Indonesia, pp. 11-14.

6. Rajagopal V, Bai KV, Shivasankar S (1991) Physiological and Biochemical basis of coconut production. CORD 7(2): 12-30.

7. Selvaraj KSV (2016) India's First Tall $\times$ Tall Coconut Hybrid Development. J Agri Res 1(1): 000106.

8. Voleti SR, Shivsankar S, Rajagopal V (1991) Comparison of physiological and biochemical parameters of coconut hybrid seedlings. Journal of Plantation Crops 18(Suppl): 104-107. 
This work is licensed under Creative Commons Attribution 4.0 License

DOI: 10.19080/ARTOAJ.2017.05.555667

\section{Your next submission with Juniper Publishers} will reach you the below assets

- Quality Editorial service

- Swift Peer Review

- Reprints availability

- E-prints Service

- Manuscript Podcast for convenient understanding

- Global attainment for your research

- Manuscript accessibility in different formats ( Pdf, E-pub, Full Text, Audio)

- Unceasing customer service

Track the below URL for one-step submission https://juniperpublishers.com/online-submission.php 